\title{
Nodulation, Nitrogen Fixation, and Organ Dry Weight of Soybean Infested with Southern Corn Rootworm (Coleoptera: Chrysomelidae) Larvae
}

\author{
PETER C. SCHROEDER, ${ }^{1}$ JOHN W. VAN DUYN, ${ }^{2}$ AND ROBERT P. PATTERSON ${ }^{3}$
}

Department of Entomology, North Carolina State University, Raleigh, NC 27695

\begin{abstract}
Environ. Entomol. 21(5): 1002-1006 (1992)
ABSTRACT Nitrogen fixation, nodulation, and organ dry weights of soybean infested with the larvae of the southern corn rootworm, Diabrotica undecimpunctata howardi Barber, were estimated under controlled conditions. Larval southern corn rootworm reduced the nitrogen-fixing activity of mid-vegetative and early reproductive soybean, Glycine max Merrill. Soybean of both stages responded to the infestation and subsequent injury by increasing nodulation and organ dry weights of below-ground tissues relative to above-ground tissues. Infestation increased the dry weight of small nodules on vegetative plants and caused a 78.6\% increase in the total number of nodules on R5 plants. Leaf area as well as leaf and stem dry weight was reduced in vegetative plants by infestation.
\end{abstract}

KEY WORDS Diabrotica undecimpunctata howardi, soybean, nitrogen fixation

SOIL-INHABITING INSECTS [e.g., rootworms, $\mathrm{Dia}$ brotica spp.; cutworms, family Noctuidae; wireworms, family Elateridae; lesser cornstalk borer, Elasmopalpus lignosellus (Zeller); grape colaspis, Colaspis brunnea (F.); white grub, Phyllophaga sp.; bean leaf beetle, Cerotoma trifurcata (Forster); and the soybean nodule fly, Rivellia quadrifasciata (Macquart)] commonly infest soybean roots (Dietz et al. 1976). Despite fundamental differences in their feeding habits, all of these insects potentially can alter the nitrogen-fixing activity and productivity of soybean. The bean leaf beetle and the soybean nodule fly have been adequately demonstrated to feed upon and subsequently injure nodules of soybean (McConnell 1915, Leonard \& Turner 1918, Eastman \& Wuensche 1977, Newsom et al. 1978, Koethe \& Van Duyn 1985, Riley et al. 1987). However, information concerning the effect of soil insect root injury on soybean nitrogen fixation and nodulation is generally lacking. In field cage tests, Riley (1986) showed greater nodule numbers on plants that were infested with three to seven bean leaf beetle larvae per $30 \mathrm{~cm}$ of row than on plants that were infested with less than one bean leaf beetle larva per $30 \mathrm{~cm}$ of row. Evidence

\footnotetext{
${ }^{1}$ Current address: Department of Entomology, New York State Agricultural Experiment Station, Cornell University, Geneva, NY 14456.

2 Current address: Department of Entomology, North Carolina State University, V. G. James Research and Extension Center, Route 2, Box 141, Plymouth, NC 27962.

${ }^{3}$ Current address: Department of Crop Science, North Carolina State University, Raleigh, NC 27695.
}

given by Riley et al. (1987) and Riley (1986) suggested a compensatory growth response by soybean to root grazing by soil arthropods.

The purpose of this study was to investigate changes in soybean nodulation, nitrogen fixation, and organ dry weights caused by root and nodule injury by larvae of the southern corn rootworm, Diabrotica undecimpunctata howardi Barber, a common soil pest of soybean in North Carolina. The southern corn rootworm can feed and develop on the root system of soybean (Meinke et al. 1985) and may occasionally damage nodule tissue (Turnipseed 1973). Injury caused by this insect to the root system of soybean is believed to contribute to yield reductions in soybean (Dietz et al. 1976), although the economic impact of this insect has not yet been determined.

\section{Materials and Methods}

The effects of larval southern corn rootworm feeding on early vegetative (experiment 1) and early reproductive (experiment 2 ) soybean were examined. Experiments were conducted within a controlled environment (A chamber) at the Southeastern Plant Environment Laboratories on the North Carolina State University campus in Raleigh. Studies evaluated changes in the organ dry weights, nodulation, and nitrogen fixation of soybean.

Experiment 1. Fifty soybean seedlings, cv. 'Ransom II', were individually grown in plastic pots $(20 \mathrm{~cm}$ diam.) containing a $3: 2$ mixture of vermiculite and gravel, respectively. Potted 
seedlings were held in a controlled-environment chamber and exposed to $26 / 22^{\circ} \mathrm{C}$ day/night temperatures and a photoperiod of $9: 15$ (L:D) h. Chambers were illuminated by both fluorescent and incandescent lamps, which together provided a photosynthetic photon fux density of 642 $\mu \mathrm{mol} / \mathrm{m}^{2} / \mathrm{s}$ (Downs \& Thomas 1983). Plants were watered daily with equal amounts of a nitrogenfree nutrient solution modified from Ahmed \& Evans (1960). All plants were inoculated with Bradyrhizobium japonicum solution prepared by suspending $30 \mathrm{~g}$ of peat-based rhizobia inoculant (Nitragin, Milwaukee, WI) in $400 \mathrm{ml}$ of distilled water. Thirty $\mathrm{ml}$ of inoculant was applied to the potting medium every other day for 3 wk after planting. Eight days after planting, 25 seedlings were each infested with six neonate southern corn rootworm. The infestation levels used in this experiment (and experiment 2 discussed below) represented, we believe, densities that plants may typically encounter in the field in North Carolina.

The nitrogen-fixing activity of 12 infested and 12 control plants was estimated at the late V4 (Fehr \& Caviness 1977) growth stage (33 d after planting) using a destructive acetylene reduction assay modified from Hardy et al. (1968). Roots were severed from the plants at soil level, gently shaken free of loose soil, and individually placed in quart $(\approx 1,000 \mathrm{ml})$ glass jars that were sealed airtight with a lid containing a rubber septum. A 40-ml aliquot of air was removed from each jar via a $50-\mathrm{ml}$ syringe, then promptly replaced with $35-\mathrm{ml}$ aliquot of pure $(99.8 \%)$ acetylene. Roots and nodules were allowed to incubate in the jar for $1 \mathrm{~h}$ before three gas samples $(\approx 1 \mathrm{ml}$ each) were taken from the jars via a $1-\mathrm{ml}$ plastic syringe and analyzed for acetylene and ethylene content using a gas chromatograph. Because the assay prevented any estimation of the endogenous ethylene produced from the physical wounding of the plant by insects, the assay may have overestimated ethylene production due to the nitrogenfixing process and, consequently, underestimated any reductions in nitrogen fixation caused by insect injury to nodules.

On the day of the assay, all 50 plants were harvested and separated into root plus nodules, stem, and leaf tissue before being dried and weighed. Nodules were removed by hand from the roots of the assayed plants $(n=24)$, then separated into small and large sizes by sifting the nodules through a $2-\mathrm{mm}$ standard testing sieve (no. 10, W. S. Tyler, Mentor, $\mathrm{OH}$ ) before being counted, dried, and weighed. Many of the small nodules and all of the large nodules contained the reddish pigment characteristic of leghemoglobin, however the small nodules may not have been fully mature or functional.

Experiment 2. Three uniform soybean seedlings, cv. 'Ransom II', were established in each of 12 pots ( $21 \mathrm{~cm}$ diam., $36 \mathrm{~cm}$ deep) containing a 3:2 vermiculite:gravel mixture. Pots were specially constructed so nitrogen fixation could be estimated without disturbing the plants (Schroeder 1989). Plants were inoculated and cultured under environmental conditions similar to those of experiment 1 . When the plants reached late vegetative growth (V5 growth stage [Fehr \& Caviness 1977]), one-half (six) of the pots were each infested with 42 (14 per plant) neonate southern corn rootworms. The remaining six pots were not infested and served as controls. Two trials were conducted from 3 April to 10 June 1988 (trial 1) and 25 January to 13 May 1989 (trial 2).

In each trial, the nitrogen-fixing activity of plants grown in three infested and three noninfested pots was estimated weekly for $4 \mathrm{wk}$ from early to mid-reproductive growth (R1, R3, R4, and R5 growth stages) using a nondestructive acetylene reduction assay (Schroeder 1989). At the R3 growth stage, plants from three infested and three noninfested pots that were not used in the assay were harvested and separated into nodule, root, stem, and leaf tissues before being dried and weighed. The remaining plants were harvested at the R5 growth stage. In the second trial, nodules collected from the harvested plants were separated into groups of small $(<2 \mathrm{~mm}$ diam.) and large ( $\geq 2 \mathrm{~mm}$ diam.) sizes as in experiment 1. Nodules within each size group were counted before being dried and weighed. Leaf area was estimated on fresh leaves collected from plants harvested in the second trial by passing the leaves through a photostatic area meter (model 3100, Li-Cor, Lincoln, NE).

Statistical Analysis. The statistical test for the effects of infestation on the nitrogen-fixing activity of soybean over several growth stages in experiment 2 was performed as a repeated measures design with trial included as a main effect variable. All other data from both trials in experiment 2 were combined for each growth stage sampled. All data from experiment 1 and combined data from experiment 2 were analyzed as a completely randomized design using analysis of variance procedures (PROC GLM, SAS Institute 1982). An $\alpha$ level of 0.05 was used as the level of significance in all tests, except when stated otherwise in the text. Two samples from each treatment $(n=4)$ in experiment 1 showed aberrant acetylene concentrations due to an accidental leak during the assay or inadequate injection of acetylene into the jars. These data were subsequently removed from the statistical analysis.

\section{Results}

Experiment 1. Infestation significantly reduced the nitrogen-fixing activity of V4 soybean (Table 1). Reductions in the nitrogen-fixing activity of infested plants coincided with reductions in the number of large nodules on these 
Table 1. Mean \pm SEM nitrogen-fixing (acetylene reduction) activity (ARA, $\mu \mathrm{mol}$ ethylene/h) and nodule specific activity (NSA, rmol ethylene/g dry nodule tissue/h) of southern corn rootworm-infested and noninfested (control) V4 soybean

\begin{tabular}{ccccc}
\hline \hline Parameter & Control & Infested & $F$ & $P>F$ \\
\hline ARA & I7.97 \pm 1.14 & $14.11 \pm 0.87$ & 7.18 & 0.0153 \\
NSA & $63.75 \pm 3.50$ & $57.32 \pm 4.31$ & 1.35 & 0.2613 \\
\hline
\end{tabular}

same plants (Table 2). Reductions in the dry weights of large nodules on infested plants were significant at the $P=0.10$ level but not at the $P=$ 0.05 level. Numbers of small nodules were not significantly affected by infestation, although infested plants contained a higher dry weight of small nodules than the control plants (Table 2). Nodule specific activity ( $\mu \mathrm{mol}$ ethylene per gram dry nodule per hour) did not differ significantly between the control and infested plants (Table 1). Although total dry weight of the plants was reduced by infestation, early vegetative soybean responded to infestation by shifting dry matter partitioning in favor of below-ground tissues (i.e., above- to below-ground dry weight ratios decreased) (Table 2). Root tissue percentage of the total plant dry weight increased while the stem tissue percentage of total plant dry weight decreased because of infestation. Infested plants showed significant reductions in stem and leaf tissue dry weights as well as leaf area.

Experiment 2. Analysis of variance of the nitrogen-fixing activity of soybean during early reproductive growth revealed no significant overall effect from trials $(F=0.182 ; \mathrm{df}=1,8$; $P>0.05)$, infestation $(F=1.213 ; \mathrm{df}=1,8 ; P>$ $0.05)$, or trials by infestation interaction $(F=$ $0.063 ; \mathrm{df}=1,8 ; P>0.05$ ). However, a significant linear effect due to plant growth stage $(F=$ 91.937; $\mathrm{df}=1,8 ; P<0.01$ ) and a significant infestation by plant growth stage interaction was

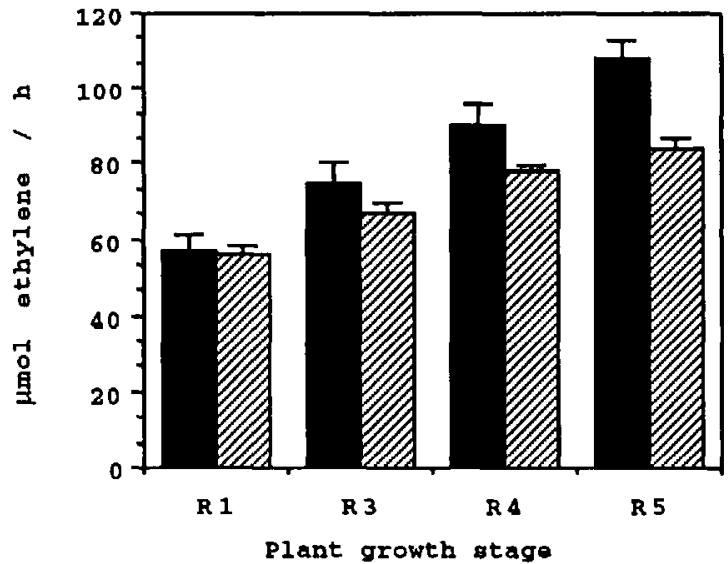

Fig. 1. Mean nitrogen-fixing activity (acetylene reduction, $\mu \mathrm{mol}$ ethylene $/ \mathrm{h}$ ) of southern corn rootworminfested and noninfested (control) soybean at the $R 1$, R3, R4, and R5 growth stages (Fehr \& Caviness 1977). Columns represent mean ( $\pm \mathrm{SEM}$ ) of six measurements (data from both trials combined) and a total activity of three plants. Solid bars, control plants; hashed bars, infested plants.

detected $(F=6.803 ; \mathrm{df}=1,8 ; P<0.05)$. Plotting the estimated mean nitrogen-fixing activity of the infested and control plants over each growth stage showed that the mean nitrogen-fixing activity of the infested plants from first bloom (Rl) to the beginning of seed-fill (R5) increased more slowly than that of the control plants (Fig. 1). A significant interaction $(F=8.588 ; \mathrm{df}=1,8 ; P<$ 0.05 ) between plant growth stage and trial was also detected and may have been caused by differences in the condition of the seed at the time of planting or slight variations in the experimental environments between trials.

Infestation caused no measurable differences in the dry weights of stem or leaf tissues, pods or

Table 2. Mean \pm SEM plant tissue dry weights ( $g$ dry tissue), plant tissue dry weight percentages ([g dry tissue/total $g$ dry tissue] $\times$ 100), above-ground to below-ground plant tissue dry weight ratios (A/B ratio), leaf area ( $\mathrm{cm}^{2}$ ), and numbers of small ( $<2 \mathrm{~mm}$ diam.) and large ( $\geq 2 \mathrm{~mm}$ diam.) nodules from plants infested or not infested (control) with southern corn rootworm larvae and harvested at the $\mathrm{V} 4$ growth stage

\begin{tabular}{|c|c|c|c|c|}
\hline Parameter ${ }^{a}$ & Control & Infested & $F$ & $P>F$ \\
\hline Leaf DWT & $0.97 \pm 0.05$ & $0.78 \pm 0.04$ & 9.04 & 0.0065 \\
\hline Stem DWT & $0.69 \pm 0.03$ & $0.50 \pm 0.02$ & 22.09 & 0.0001 \\
\hline Root DWT & $0.42 \pm 0.02$ & $0.38 \pm 0.01$ & 3.74 & 0.0660 \\
\hline Nod. DWT & $0.27 \pm 0.02$ & $0.26 \pm 0.01$ & 0.77 & 0.3893 \\
\hline Total DWT & $2.36 \pm 0.11$ & $1.91 \pm 0.07$ & 11.85 & 0.0023 \\
\hline$\%$ leaf DWT & $41.05 \pm 0.58$ & $40.39 \pm 0.71$ & 0.53 & 0.4765 \\
\hline \% stem DWT & $29.36 \pm 0.46$ & $26.27 \pm 0.57$ & 18.00 & 0.0003 \\
\hline$\%$ root DWT & $17.88 \pm 0.26$ & $19.81 \pm 0.31$ & 22.38 & 0.0001 \\
\hline$\%$ nod. DWT & $11.71 \pm 0.62$ & $13.53 \pm 0.79$ & 3.32 & 0.0821 \\
\hline A/B ratio & $2.39 \pm 0.07$ & $2.02 \pm 0.07$ & 14.51 & 0.0010 \\
\hline Leaf area & $367.71 \pm 13.24$ & $306.98 \pm 9.31$ & 14.08 & 0.0005 \\
\hline Small nod. DWT & $0.04 \pm 0.01$ & $0.06 \pm 0.01$ & 5.68 & 0.0263 \\
\hline Large nod. DWT & $0.23 \pm 0.02$ & $0.19 \pm 0.02$ & 3.13 & 0.0906 \\
\hline Small nod. no. & $106.42 \pm 8.63$ & $108.17 \pm 9.42$ & 0.02 & 0.8923 \\
\hline Large nod. no. & $127.08 \pm 6.53$ & $106.92 \pm 6.76$ & 4.60 & 0.0433 \\
\hline
\end{tabular}

${ }^{a}$ DWT $=$ dry weight; nod. $=$ nodules. 
Table 3. Mean \pm SEM plant tissue dry weights (g dry tissue), plant tissue dry weight percentages ([g dry tissue/total $\mathrm{g}$ dry tissue] $\times 100)$, above-ground to below-ground plant tissue dry weight ratios $\left(A / B\right.$ ratio), leaf area $\left(\mathrm{cm}^{2}\right)$, and numbers of small ( $<2 \mathrm{~mm}$ diam.) and large ( $\geq 2 \mathrm{~mm}$ diam.) nodules from plants infested or not infested (control) with southern corn rootworm larve and harvested at the $R 3$ and $R 5$ growth gtages

\begin{tabular}{|c|c|c|c|c|}
\hline Parameter $^{a}$ & Control & Infested & $F$ & $P>F$ \\
\hline \multicolumn{5}{|l|}{ R3 growth stage } \\
\hline Leaf DWT & $11.71 \pm$ & $11.95 \pm$ & 0.08 & 0.7855 \\
\hline Pod DWT & $2.48 \pm$ & $2.53 \pm$ & 0.05 & 0.8315 \\
\hline Stem DWT & $8.56 \pm$ & $8.65 \pm$ & 0.01 & 0.9131 \\
\hline Root DWT & $2.69 \pm$ & $2.90 \pm$ & 0.44 & 0.5233 \\
\hline Nod. DWT & $2.63 \pm$ & $3.09 \pm$ & 4.01 & 0.0731 \\
\hline Total DWT & $28.07 \pm$ & $29.09 \pm$ & 0.23 & 0.6413 \\
\hline$\%$ leaf DWT & $41.81 \pm$ & $41.07 \pm$ & 0.69 & 0.4241 \\
\hline$\%$ pod DWT & $8.98 \pm$ & $8.68 \pm$ & 0.13 & 0.7282 \\
\hline \% stem DWT & $30.34 \pm$ & $29.69 \pm$ & 0.44 & 0.5223 \\
\hline$\%$ root DWT & $9.52 \pm$ & $9.91 \pm$ & 0.56 & 0.4706 \\
\hline \% nod. DWT & $9.35 \pm$ & $10.65 \pm$ & 3.29 & 0.0999 \\
\hline A/B ratio & $4.31 \pm 0.11$ & $3.88 \pm 0.13$ & 6.04 & 0.0338 \\
\hline Leaf area & $3,365.46 \pm 94.94$ & $3,409.64 \pm 244.59$ & 0.03 & 0.8744 \\
\hline No. small nod. & $152.67 \pm 36.75$ & $430.00 \pm 69.62$ & 12.41 & 0.0244 \\
\hline $\begin{array}{l}\text { No. large nod. } \\
\text { R5 growth stage }\end{array}$ & $884.67 \pm 57.23$ & $760.67 \pm 56.32$ & 3.55 & 0.1327 \\
\hline Leaf DWT & $14.44 \pm$ & $14.20 \pm$ & 0.05 & 0.8218 \\
\hline Pod DWT & $13.24 \pm$ & $12.92 \pm$ & 0.05 & 0.8279 \\
\hline Stem DWT & $11.11 \pm$ & $11.14 \pm$ & 0.00 & 0.9875 \\
\hline Root DWT & $2.97 \pm$ & $3.47 \pm$ & 1.88 & 0.2006 \\
\hline Nod. DWT & $5.32 \pm$ & $5.84 \pm$ & 0.48 & 0.5049 \\
\hline Seed DWT & $22.60 \pm$ & $20.82 \pm$ & 0.12 & 0.7362 \\
\hline Total DWT & $69.67 \pm$ & $68.38 \pm$ & 0.02 & 0.9013 \\
\hline$\%$ leaf DWT & $21.35 \pm$ & $21.34 \pm$ & 0.00 & 0.9926 \\
\hline$\%$ pod DWT & $19.28 \pm$ & $19.22 \pm$ & 0.00 & 0.9486 \\
\hline$\%$ stem DWT & $16.06 \pm$ & $16.29 \pm$ & 0.64 & 0.4433 \\
\hline$\%$ root DWT & $4.31 \pm$ & $5.16 \pm$ & 10.30 & 0.0094 \\
\hline$\%$ nod. DWT & $7.62 \pm$ & $8.65 \pm$ & 14.90 & 0.0032 \\
\hline$\%$ seed DWT & $31.38 \pm$ & $29.35 \pm$ & 0.46 & 0.5119 \\
\hline $\mathrm{A} / \mathrm{B}$ ratio & $4.75 \pm$ & $4.12 \pm \quad 0.06$ & 15.78 & 0.0026 \\
\hline Leaf area & $3,684.35 \pm 123.69$ & $3,364.58 \pm 200.84$ & 1.84 & 0.2467 \\
\hline No. small nod. & $193.33 \pm 46.21$ & $905.67 \pm 133.86$ & 25.30 & 0.0073 \\
\hline No. large nod. & $989.33 \pm 37.21$ & $1,206.67 \pm 59.48$ & 9.60 & 0.0363 \\
\hline
\end{tabular}

${ }^{a} \mathrm{DWT}=\mathrm{dry}$ weight; nod. = nodules.

seed, or leaf areas of soybean (Table 3). Similarly, root tissue dry weights did not differ significantly between infested and control plants, although nodule tissue dry weight of all nodules differed at the $P=0.10$ level but not at the $P=$ 0.05 level at the R3 growth stage. Though the effects of infestation on root or nodule dry weights were not significant at the $P=0.05$ level, above- to below-ground tissue dry weight ratios were significantly different between infested and control plants at the R3 and R5 growth stages (Table 3). Roots and nodules of infested plants obtained a greater percentage of the total plant dry weight than did the roots and nodules of control plants at the seed-filling (R5) stage (Table 3). Roots infested with southern corn rootworm larvae were visibly more branched (fibrous) than those of noninfested plants. Also, infested roots contained many small $(\approx 1 \mathrm{~mm}$ diam.) outgrowths. These outgrowths were not confirmed as either newly formed nodules or adventitious roots; however, many small and large nodules (evidenced by the presence of leghemoglobin) were present among the smaller nodule-shaped outgrowths. Small nodules numbered 2.8- and 4.7-fold greater on infested plants than on control plants at the R3 and R5 growth stages, respectively (Table 3 ). Infested plants also contained greater numbers of large nodules than control plants at the R5 growth stage. Total number of nodules on infested plants significantly increased $(F=19.35$; df $=1,4 ; P=0.0117)$ between the R3 and R5 growth stages. Changes in the total nodule numbers on the control plants between the two growth stages were significant at the $P=0.10$ level but not at the $P=0.05$ level $(F=5.345 ; \mathrm{df}=1,4 ; P=0.0819)$.

\section{Discussion}

Both vegetative and reproductive soybean responded to infestation by shifting dry matter accumulation in favor of below-ground plant tissues. Changes in plant growth were primarily exhibited by an inhibition of shoot growth and leaf area expansion in vegetative soybean and a stimulation of lateral root growth and nodulation in reproductive soybean. Root feeding by southern corn rootworm larvae reduced the nitrogenfixing activity of soybean and may have restricted nitrogen assimilation by the plants. 
Insect injury to soybean roots and nodules may alter normal plant growth and function. These changes are undoubtedly complex and may result from either the direct or indirect effects of arthropod feeding and/or activity. Injuries caused by insects to the roots and nodules of soybean may interact with other abiotic and biotic stresses that influence the Bradyrhizobium japonicum/soybean symbiosis or alter endogenous plant hormone levels and activity. The ability of soybean to recover from insect injury may depend largely on the availability of alternate sources of nitrogen. The effect of insect-induced root injury on the ability of soybean to obtain nitrogen in the field has not been studied. The increased branching of roots on infested plants may allow these plants to better acquire nutrients, including free nitrogen, from the soil. Additional or more detailed research is needed to clarify the effects of soil insects on the nodulation and nitrogen-fixing processes in soybean and the ultimate effect on soybean yield.

\section{Acknowledgments}

We thank C. Browne for assisting in the statistical analysis of the research data; D. W. Israel and A. G. Wollum III for providing technical support and wisdom regarding various aspects of plant culture and sampling; R. J. Downs and J. Thomas, as well as other members of the Southeastern Experimental Plant Environment Laboratory staff, for technical assistance in the use of the Phytotron facilities; and C. S. Ferguson for reviewing early versions of the manuscript. This article represents a portion of a dissertation presented to the graduate faculty, North Carolina State University, Raleigh, by the senior author as partial fulfillment of the degree of Doctor of Philosophy. Partial funding for this research was provided by the North Carolina Soybean Producers Association.

\section{References Cited}

Ahmed, S. \& H. J. Evans. 1960 . Cobalt: a micronutrient element for the growth of soybean under symbiotic conditions. Soil Sci. 90: 205-210.

Dietz, L. L., J. W. Van Duyn, J. R. Bradley, Jr., R. L. Rabb, W. M. Brooks \& R. E. Stinner. 1976. A guide to the identification and biology of soybean arthropods in North Carolina. N.C. Agric. Exp. Stn. Tech. Bull. 238.

Downs, R. J. \& J. F. Thomas. 1983. Phytotron procedural manual for controlled environment re- search at the Southeastern Plant Environment Laboratory. N.C. Agric. Res. Serv. Tech. Bull. 244.

Eastman, C. E. \& A. L. Wuensche. 1977. A new insect damaging nodules of soybean: Rivellia quadrifasciata (Macquart). J. Ga. Entomol. Soc. 12: 190-199.

Fehr, W. C. \& C. E. Caviness. 1977. Stages of soybean development. Iowa Cooperative Extension Service Spec. Rep. 80.

Hardy, R.W.F., R. D. Holstein, E. K. Jackson \& R. C. Burns. 1968. The acetylene-ethylene assay for $\mathrm{N}_{2}$ fixation: laboratory and field evaluation. Plant Physiol. (Bethesda) 43: 1185-1207.

Koethe, R. W. \& J. W. Van Duyn. 1985. Aspects of larvahost relations of the soybean nodule fly, Rivellia quadrifasciata (Diptera: Platystomatidae). Environ. Entomol. 13: 945-947.

Leonard, L. T. \& C. F. Turner. 1918. Influence of Cerotoma trifurcata on the nitrogen-gathering functions of cowpea. J. Am. Soc. Agron. 10: 256261.

McConnell, W. R. 1915. A unique type of insect injury. J. Econ. Entomol. 8: 261-266.

Meinke, L. J., F. Gould \& J. W. Van Duyn. 1985. Soybean: a larvae host for the southern corn rootworm (Coleoptera: Chrysomelidae). Fla. Entomol. 68: 496-498.

Newsom, L. D., E. P. Dunigan, C. E. Eastman, R. L. Hutchinson \& R. M. McPherson. 1978. Insect injury reduces nitrogen fixation in soybean. La. Agric. 21: 15-16.

Riley, D. G. 1986. Soil arthropods associated with the soybean root system, Glycine $\max (\mathrm{L}$.) Merrill, with emphasis on immature bean leaf beetle, Cerotoma trifurcata Forster (Coleoptera: Chrysomelidae). M.S. thesis, North Carolina State University, Raleigh.

Riley, D. G., G. J. House \& J. W. Van Duyn. 1987. Effects of phorate on soil arthropods and soybean productivity in a North Carolina coastal plain cropping system. J. Entomol. Sci. 4: 317-323.

SAS Institute. 1982. SAS user's guide: statistics. SAS Institute, Cary, NC.

Schroeder, P. C. 1989. Effects of select soilarthropods on nitrogen fixation (acetylene reduction), nodulation, and dry matter partitioning of soybean. Ph.D. dissertation, North Carolina State University, Raleigh.

Turnipseed, S. G. 1973. Insects, pp. 545-572. In B. E. Caldwell [ed.], Soybeans: improvement, production, and uses. American Society of Agronomy, Madison, WI.

Received for publication 20 November 1991; accepted 15 June 1992. 